\title{
Vegetation pattern and sedimentation changes in the context of the Lateglacial climatic events: Case study of Staroje Lake (Eastern Belarus)
}

\author{
Valentina Zernitskaya ${ }^{a}$, Miglè Stančikaite ${ }^{b}$, Boris Vlasov ${ }^{c}$, Vaida Šeirienè ${ }^{\text {b, * }}$, \\ Dalia Kisielienè b, Gražyna Gryguc ${ }^{\text {b }}$, Raminta Skipitytè b, d \\ a Institute for Nature Management, National Academy of Sciences, Belarus, F. Skoriny Str. 10, 220114, Minsk, Belarus \\ ${ }^{\mathrm{b}}$ Nature Research Centre, Institute of Geology and Geography, T. Ševčenkos Str. 13, LT 03223, Vilnius, Lithuania \\ ' Belarusian State University, Nezavisimosti Avenue 4, 220030, Minsk, Belarus \\ ${ }^{\mathrm{d}}$ Center for Physical Sciences and Technology, Institute of Physics, Savanoriu 231, LT-02300, Vilnius, Lithuania
}

\section{A R T I C L E I N F O}

\section{Article history:}

Available online 13 July 2014

\section{Keywords:}

Palaeobotany

Stable isotope

Palaeoenvironmental changes

Lateglacial

Belarus

\begin{abstract}
A B S T R A C T
A lake sediment core collected from the Staroje Lake, southeastern Belarus, reveals significant changes of the terrestrial and limnic environmental during the Lateglacial and Early Holocene in the periglacial zone of the Late Weichselian Glaciation. The combination of lithological (loss-on-ignition), palaeobotanical (pollen, non-pollen palynomorphs, diatoms) and isotopic $\left(\delta^{18} \mathrm{O}, \delta^{13} \mathrm{C},{ }^{14} \mathrm{C}\right)$ proxy parameters was applied for the reconstruction of the vegetation pattern and sedimentation regime. The Lateglacial preInterstadial (GS-2) vegetation was dominated by mineral-soil pioneers with scattered occurrence of Pinus and Betula; an Interstadial (GI-1) dominated by Pinus forest with increasing representation of openground species since approximately 13,500 cal BP; and Lateglacial Stadial (GS-1) with recurring opening of the vegetation pattern with scattered tree patches including those of Picea. Presence of Pinus stomata confirms the local origin of this plant since the pre-Interstadial. Starting from the Holocene, birch, later accompanied by other deciduous species (Ulmus, Alnus, Quercus, Corylus), took over in the local vegetation structure.

Isotopic records $\left(\delta^{18} \mathrm{O}, \delta^{13} \mathrm{C}\right)$ obtained on bulk carbonates as well as diatom data exhibit several shifts reflecting variations both in terrestrial and limnic environment. Distinct negative excursion of $\delta^{18} \mathrm{O}$ curve recorded during the first half of the GI-1 event suggests intensive groundwater discharge accompanied by active transportation of detrital carbon in to the basin. Limited basin productivity is also indicated by lithological and diatom records. Since approximately 13,700 cal BP, sedimentation regime in the lake stabilised and productivity of the basin started to increase in positive correlation with LOI data. A considerable decrease in $\delta^{18} \mathrm{O}$ values punctuated by a rapid jump in the middle of the interval was recorded during the GS-1 Stadial and could be associated with the deterioration of the environmental regime and degradation of the soil layer, increasing erosion activity alongside the rising input of detrital carbonates into the basin. The water table was low, as indicated by diatom data. Recovery of the environmental regime preceded the GS-1/Holocene boundary, as is seen in lithostratigraphical and isotopic data. During the early Holocene, stable isotopes show several episodes with altered levels suggesting instability of the environmental regime, most probably related with the global climatic alterations.
\end{abstract}

() 2014 Elsevier Ltd and INQUA. All rights reserved.

\section{Introduction}

The Last Glacial Termination was characterized by numerous environmental oscillations recorded in terrestrial, glacial, and marine proxy records collected from around the North Atlantic realm.

\footnotetext{
* Corresponding author

E-mail address: seiriene@geo.lt (V. Šeirienè).
}

At the same time, the wide climatic instability (Walker, 1995; von Grafenstein et al., 1999; Lowe et al., 2008; Brooks and Birks, 2000a,b) related to the changes of thermohaline circulation and solar activity among other factors have been confirmed. Insights into the pattern of these changes are crucial to predicting future environmental and climatic regimes.

While numerous studies have revealed and characterised Lateglacial vegetation and sedimentation dynamics (Starkel, 2002; 


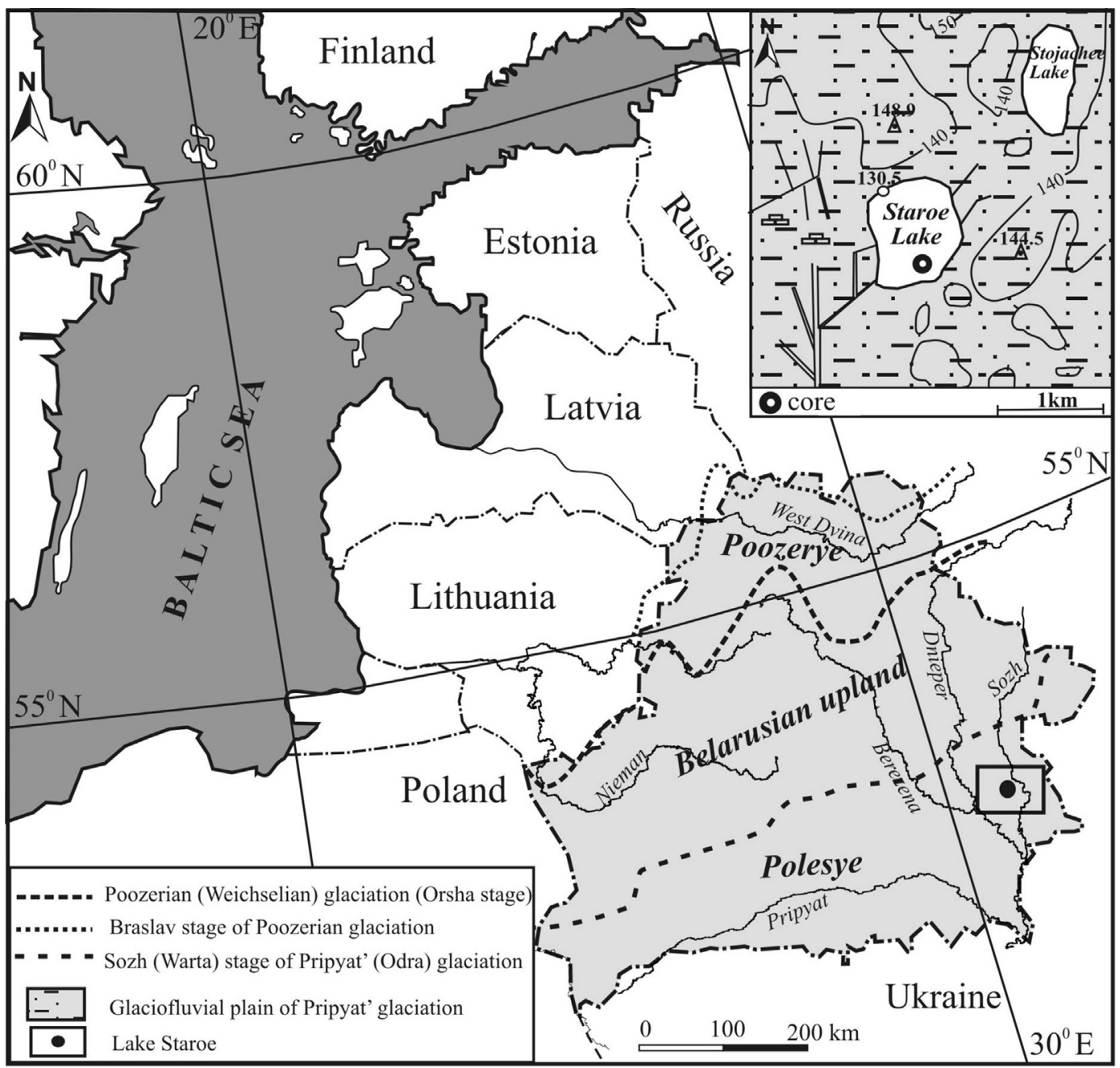

Fig. 1. Situational map of the Belarus territory showing the position of Staroje Lake and location of the ice marginal zones.

Birks and Birks, 2004; Willis and van Andel, 2004; Giesecke, 2005a,b; Latałowa and van der Knaap, 2006; Margielewski, 2006; Birks and Willis, 2008; Binney et al., 2009) in northern, northwestern and central Europe fewer sedimentary records exist for the eastern part of the continent including western and northwestern Russia, Belarus and Ukraine (Zernitskaya et al., 2001; Makhnach et al., 2004; Wohlfarth et al., 2006; Novenko et al., 2009; Väliranta et al., 2011). The existing data sets suggest a high synchronicity of the main climatic events and the associated environmental response circum North Atlantic (Lowe et al., 2008), while some alterations, such as the delay of the early Holocene warming and the subsequent environmental shifts were fixed in the north-eastern part of the European continent (Wohlfarth et al., 1999, 2002, 2004, 2006, 2007; Subetto et al., 2002; Stančikaite et al., 2008, 2009).

Discussing the different aspects of the Lateglacial environmental pattern, the Eastern European territories situated outside the maximum extent of the Scandinavian Ice sheet are of crucial importance, as numerous processes, including forestation of the newly deglaciated areas, started from the periglacial zone. As the major part of the Belarusian territory was free of ice during the Last Glacial maximum, this region provides exceptional opportunities for multi-proxy palaeoenvironmental and palaeoclimatic reconstructions, filling the gap between the western and eastern European databases. According to existing information, the processes of the lacustrine sedimentation started before $12.8 \mathrm{ka} \mathrm{BP}$ (Matveyev et al., 1993; Zernitskaya et al., 2001; Zernitskaya and Mikhailov, 2009) in Belarus. However, the main Lateglacial sites are located in central, western, and southwestern parts of the country. Late Glacial deposits of Eastern Belarus are poorly studied and have been restricted to palynological stratigraphy. In the present study, we attempt to achieve more detailed knowledge on the Late Glacial and Early Holocene establishment of the plant cover, development of the sedimentary environment, and changes of climatic regime in this poorly studied region in southeastern Belarus. This study investigated regional climatic changes in the context of supra-regional climatic events, documented in the GISP2 Greenland ice core (Stuiver et al., 1995). Increasing the number of chronologically well-supported high-resolution multi-proxy archives representing areas where the number of similar investigations is still low may aid in improving the understanding of the Lateglacial climatic evolution and the ecosystem reaction in the Northern Hemisphere.

\section{Site description}

Lake Staroje $\left(52^{\circ} 51^{\prime} \mathrm{N}, 30^{\circ} 58^{\prime} \mathrm{E}, 130.5 \mathrm{~m}\right.$ a.s.l., Chechersk district, Gomel oblast) situated in southeastern Belarus (Fig. 1) lies in the glacial meltwater channel (depth $15-20 \mathrm{~m}$ ) formed during the Pripyat' Glaciation (Dnieper stage or Saale II). In the northern and 
eastern part of the depression, slopes reached up to $10-15 \mathrm{~m}$ height, reaching only $3 \mathrm{~m}$ along the southwest and northeast edges. The investigated basin is a high eutrophic lake in the basin of the Sozh River, a tributary of the Dnieper River (Fig. 1). Quaternary tills and glaciofluvial deposits (max. 20-50 m and min. $10-15 \mathrm{~m}$ in depressions) are underlain by Paleogene-Neogene sediments and Upper Cretaceous marl or limestone (Matveyev et al., 1988). Staroje Lake (area $0.63 \mathrm{~km}^{2}$ ) is $1.1 \mathrm{~km}$ long, $0.8 \mathrm{~km}$ at its maximum width, and has a maximum depth of $5.0 \mathrm{~m}$. The catchment of the lake covers $18.8 \mathrm{~km}^{2}$. The maximum thickness of bottom deposits varies around $9.0 \mathrm{~m}$. Despite the proximity of Staroje Lake, situated in the upper part of the glacial channel (Fig. 1), no direct connection between these lakes existed.

Two small drainage channels enter the lake, and one has its source here (Fig. 1). The coastal sites of the lake are covered by shrubs, and bogs along the south. The study area is located in the hornbeam-oak-dark-coniferous zone, but the vicinity of the lake has been cleared of forest. The climate is moderately continental: mean July temperature is $+18.0{ }^{\circ} \mathrm{C}$ and that of January $-7.5{ }^{\circ} \mathrm{C}$. Mean annual precipitation reaches $650 \mathrm{~mm}$ (Loginov, 1996).

\section{Field and laboratory work}

\subsection{Coring and sampling}

Two cores of $7.5 \mathrm{~cm}$ diameter were recovered from Staroje Lake in February 2013, using a "Russian" corer. The winter coring took place through ice when parallel sediment sequences reaching up to $733 \mathrm{~cm}$ depth were recovered from under $150 \mathrm{~cm}$ of water (the water surface is the zero point). The coring place was situated $200 \mathrm{~m}$ from the southeastern shore of the lake. The obtained sediments were packed in plastic cases ( $1 \mathrm{~m}$ long) and transported to the laboratory of the Institute for Nature Management, National Academy of Sciences, Belarus. There, sediments were carefully described and subsampled in $2 \mathrm{~cm}$ slices for further analyses. The samples from the 523-732 cm interval discussed in this paper were stored at $4{ }^{\circ} \mathrm{C}$. Pollen analysis and survey of non-pollen palynomorphs were performed at the Institute for Nature Management, Belarus, while the lithological (LOI) survey, diatom investigations and isotopic $\left(\delta^{18} \mathrm{O}\right.$ and $\left.\delta^{13} \mathrm{C}\right)$ measurements were carried out at the Nature Research Centre, Lithuania, and AMS ${ }^{14} \mathrm{C}$ dating at the Poznan Radiocarbon Laboratory, Poland.

\subsection{Loss on ignition}

In order to identify the content of organic matter (OM), calcium carbonate $\left(\mathrm{CaCO}_{3}\right)$, and terrigenous component in the sediments, loss-on-ignition (LOI) survey was applied. Sediment samples of $5 \mathrm{~cm}^{3}$ representing $4 \mathrm{~cm}$ of the sediment column each were dried at $105^{\circ} \mathrm{C}$ for $24 \mathrm{~h}$ and combusted at $500{ }^{\circ} \mathrm{C}$ for $4 \mathrm{~h}$ for the burning of organic matter. The following stage was four hours burning at $900{ }^{\circ} \mathrm{C}$ for the destruction of the carbonates. The results of the test runs (Heiri et al., 2001) were taken into account in carrying out the experiments. Organic matter, carbonate and mineral proportions were determined. In total, 78 samples were measured.

\section{3. ${ }^{14} \mathrm{C}$ dating}

The chronology of the investigated sediments was based on the results of four AMS radiocarbon dates obtained from the bulk samples and biostratigraphical information obtained from a regional scale. The radiocarbon dates were transformed to calibrated ones using the OxCal v4.2 software (Bronk Ramsey et al., 2010) with the IntCal13 calibration curve (Reimer et al., 2013). All dates are given at the $2 \sigma$ confidence level (95.4\%) and expressed in cal BP.

\subsection{Pollen and non-pollen palynomorph analysis}

A total of 104 sub-samples of $2 \mathrm{~cm}^{3}$ fresh sediment, covering $2 \mathrm{~cm}$ intervals, were prepared using the standard methodology described by Erdtman (1936) that included treatment by heavy liquid $\left(\mathrm{ZnCl}_{2}\right)$ (Berglund and Ralska-Jasiewiczowa, 1986). Lycopodium tablets were added to enable pollen concentrations to be estimated (Stockmarr, 1971). The mean number of the terrestrial pollen counted was 500 grains/sample, varying from 276 to 880 . Pollen and spore identification was based on Moore et al. (1991) and Reille (1992). Furthermore, the Pinaceae stomata, algae, fungi and amoebae fauna (Rhizopoda) were fixed in the pollen slides following Jankovská and Komárek (2000), Bobrov et al. (1999), Booth (2002), and Sweeney (2004). The percentage pollen values were calculated on the basis of arboreal and non-arboreal pollen sum $\left(\sum A P+\sum N A P=\sum P\right)$. Percentages of aquatic pollen and ferns/mosses spores as well as of non-pollen palynomorphs were calculated on the basis of $\sum \mathrm{P}+$ sum of corresponding grains $=100 \%$. All spreadsheets and the percentage diagrams were plotted using the programs Tilia and Tilia Graph (Grimm, 1992) with the application of incremental sum of squares cluster analysis (Grimm, 2007) for the zonation of the records. The local pollen assemblage zones (LPAZ) are defined on the basis of visual and statistical interpretation of the pollen spectra.

\subsection{Diatom survey}

Diatoms were extracted from the 56 sediment samples using the conventional technique described by Battarbee (1986), identified under NIKON light microscope at $1000 \times$ magnification, and more than 500 specimens were counted per sample. Species identification primarily followed Krammer and Lange-Bertalot (1988, 1991a,b, 1997). The local diatom assemblage zones (LDAZ) are defined on the basis of the visual changes in species composition throughout the section, and statistical treatment.

\section{6. $\delta^{18} \mathrm{O}$ and $\delta^{13} \mathrm{C}$ ratio analysis}

Sub-samples of bulk sediments were taken at $2 \mathrm{~cm}$ increments of the core, for a total of 167 samples. Sample preparation and measurements mainly followed the method described by Zha et al. (2010) and Spötl and Vennemann (2003). Samples were oven-dried at $105^{\circ} \mathrm{C}$ for $24 \mathrm{~h}$ prior to measurement, then manually ground to a fine powder with agate mortar and pestle. Stable isotope analyses were done by analyzing carbon dioxide produced during the reaction of carbonate with $100 \% \mathrm{H}_{3} \mathrm{PO}_{4}$ at $70^{\circ} \mathrm{C}$ for $1 \mathrm{~h}$. The $\delta^{18} \mathrm{O}$ and $\delta^{13} \mathrm{C}$ of samples were measured using a carbonate preparation device (GasBenchII) coupled to a stable isotope mass spectrometer (Thermo Scientific Delta V Advantage). Carbon and oxygen isotope data are reported as $\delta \mathrm{X}$ values (where $\mathrm{X}$ represents the heavier isotope ${ }^{13} \mathrm{C}$ or ${ }^{18} \mathrm{O}$ ) or differences from the given standards, expressed in parts per thousand (\%o) and are calculated according to the formula: $\delta X=[$ Rsample/Rstandard -1$]{ }^{*} 103$. Precision for carbon and oxygen isotope analyses was $0.06 \%$ and $0.1 \%$ respectively. All values are reported relative to VPDB.

\section{Results}

\subsection{Lithostratigraphy}

Based on the results of loss-on-ignition measurements, four main lithostratigraphic units have been distinguished in the 


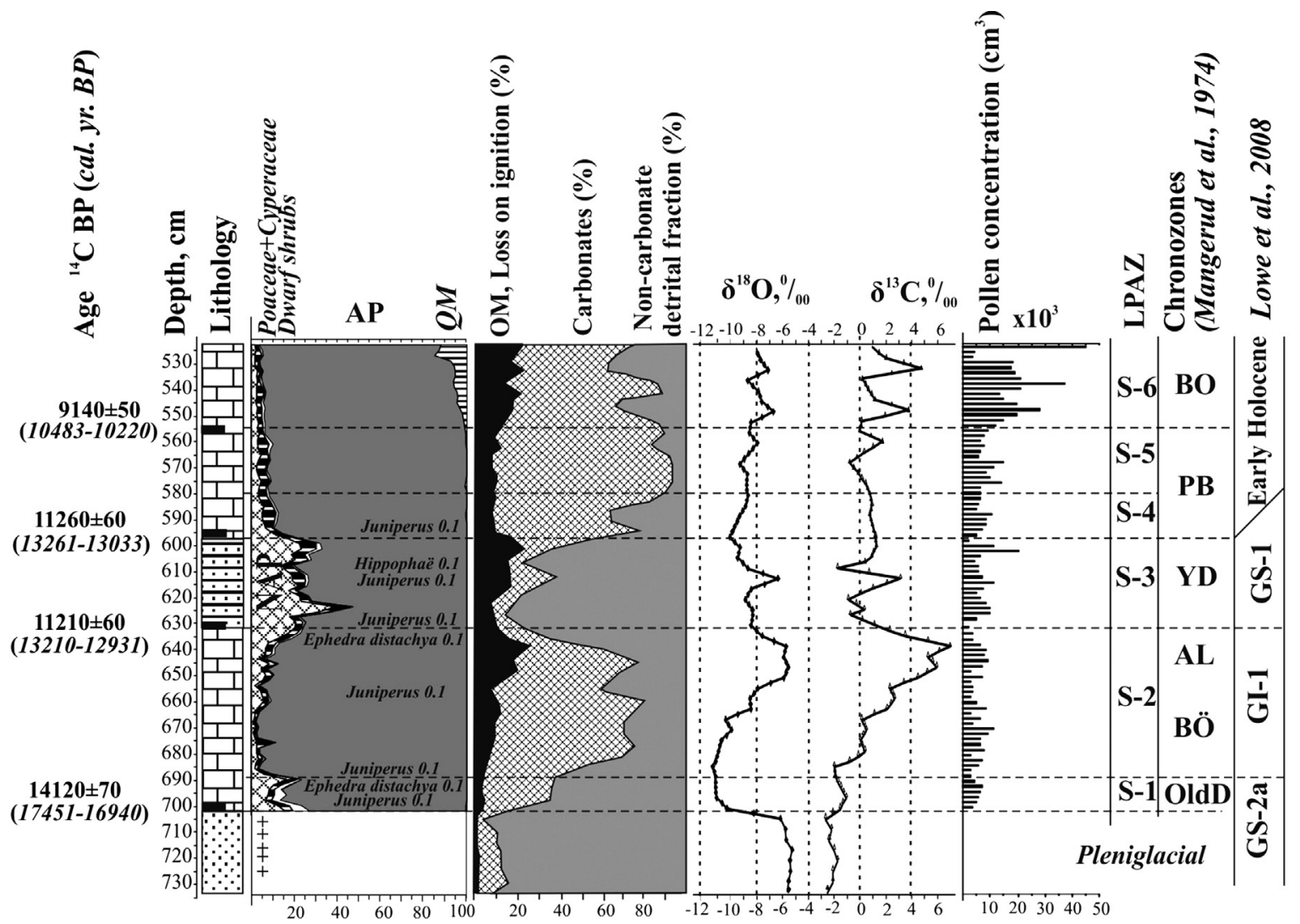

A)

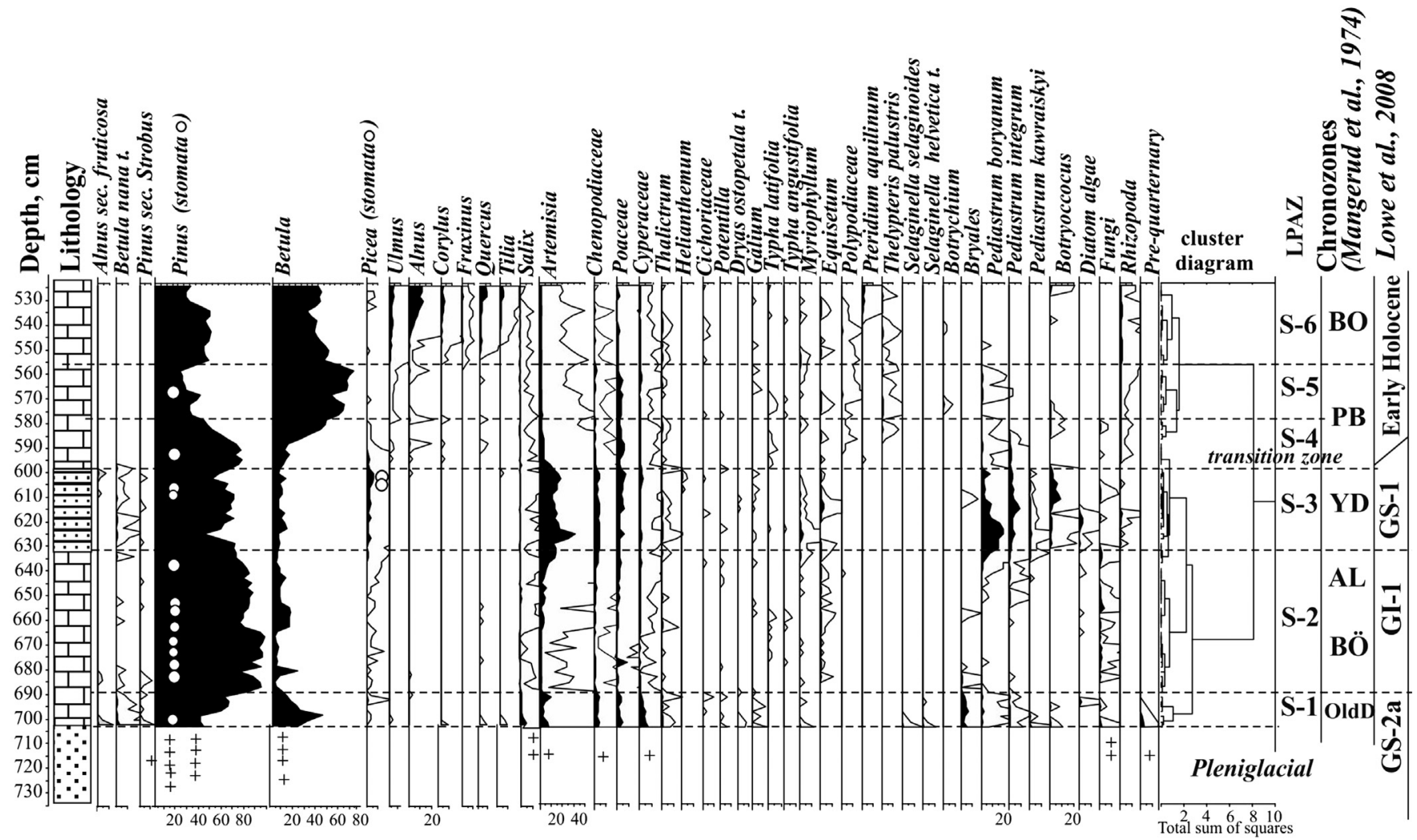

B) $\quad$ calcareous gyttja $\because$.:? silty calcareous sand $\because \because \because$ sand

Fig. 2. Results of LOI and $\delta^{18} \mathrm{O}$ and $\delta^{13} \mathrm{C}$ measurements (A) with pollen and non-pollen palynomorph (A, B) data from Lake Staroje sediments (OM - organic matter, QM - $\sum$ Ulmus, Quercus, Tilia). Pollen, non-pollen palynomorphs analysed by V. Zernitskaya, stable isotopes - R. Skipitytè, LOI - G. Gryguc. 
sediments of Staroje Lake (Fig. 2). The lake bed $(703-733 \mathrm{~cm}$ ) consists of yellow sand of varied texture with a negligible admixture of $\mathrm{OM}(2.2 \%)$, and $\mathrm{CaCO}_{3}$ (up to $15.7 \%$ ). Amount of the latter distinctly increases in the overlying light grey calcareous gyttja unit $2(633-703 \mathrm{~cm})$, that also became more organic-rich towards the upper contact $(26.1 \%)$. Unit $3(599-633 \mathrm{~cm})$ is organic-poor silty calcareous sand, laminated between 610 and $618 \mathrm{~cm}$, where the OM increased to $23.7 \%$ approaching the upper contact. The proportion of $\mathrm{CaCO}_{3}$ throughout the unit varies around $10 \%$. However, a short enrichment of $\mathrm{CaCO}_{3}$ (up to 24.0\%) was recorded at the depth of $613 \mathrm{~cm}$. A sharp transition to calcareous gyttja is coincident with the onset of unit $4(523-599 \mathrm{~cm})$ where $\mathrm{CaCO}_{3}$ increases to $86.6 \%$ while OM is less than $10 \%$. Enrichment in the organic constituent was recorded in the upper part of the unit.

\subsection{Chronology}

As the number and preservation of discovered plant macrofossils was minor in the investigated part of the core, bulk sediment samples were analyzed. However, radiocarbon dating of calcareous enriched sediments is problematic because it easily overestimates ages due to the reservoir effect (Mook and Streurman, 1983), which is difficult to quantify. For this reason, biostratigraphical information obtained on the regional scale and supported by ${ }^{14} \mathrm{C}$ data (Zernitskaya et al., 2005) was applied to assess the age of the Staroje Lake record. Under the assumption of the synchronicity between Greenland and European climatic events, changes in oxygen-isotope curve were also taken into account in discussing the chronology of the events identified (Schwander et al., 2000; Ammann et al., 2013a,b).

S-1 pollen zone (Fig. $2 \mathrm{~A}, \mathrm{~B}$ ) reflects a rather open landscape when the shrub/tundra and forest/tundra vegetation with local stands of Pinus flourished. Unfortunately, due to the high quantity of redeposited material that may include both older deposits containing carbonate and "old carbon" itself that determinated so-called "hard water" effect, the obtained ${ }^{14} \mathrm{C}$ date $(17,451-16,940$ cal BP, Poz-58619, $701-702 \mathrm{~cm}$, Table 1) produced a remarkably "older than expected" age. Therefore, based on the correlation of biostratigraphical (palynostratigraphy) data including that obtained on a regional scale (Zernitskaya et al., 2005) the age is estimated to be around 15,500-14,500 cal BP, i.e. the end of the Pleniglacial or GS-2 event (Lowe et al., 2008). Subsequently, expansion of Pinus accompanied by temporary decline of Betula was observed in the pollen record (S-2). This time of the pine prosperity correspond to the Lateglacial Interstadial in Belarus, 14,700-13,000 cal BP (Matveyev et al., 1993; Makhnach et al., 2009; Zernitskaya et al., 2010) and could be correlated with the GI-1 event (Lowe et al., 2008). The onset of the LPAZS-3 is marked by the strong decline of AP taxa, suggesting an opening of the vegetation structure. Simultaneously, a characteristic drop in the $\delta^{18} \mathrm{O}$ curve occurred, indicating deterioration of the climatic regime. These changes appear to reflect the onset of the Younger Dryas (Makhnach et al., 2009, 2010) or GS-1 event sensu Lowe et al. (2008). The obtained AMS date suggests this event occurred at approximately 13,200-12,900 cal BP (Poz-58617, Table 1) in the surroundings of Staroje Lake. At the transition to pollen zone S-4, the number of herbaceous taxa sharply declined, suggesting occupation of the terrain by forest vegetation. However, Picea pollen dropped simultaneously, indicating extinction of this tree from the local vegetation. According to Novik et al. (2010) this event was dated to approximately 11,700 cal BP $\left(10,110 \pm 130{ }^{14} \mathrm{CBP}\right.$, IGSB-802) in the region. The AMS date yielded from the above mentioned transition indicated a remarkably older age i.e. 13,262-13,033 cal BP (Poz-58616, Table 1) which could have resulted from detrital carbon content. The uppermost part of the profile (S-4 and S-5 pollen zones) suggests an Early Holocene age of the investigated strata, both from the palaeobotanical and isotopic points of view.
Table 1

${ }^{14} \mathrm{C}$ data from Staroje Lake.

\begin{tabular}{llrlll}
\hline $\begin{array}{l}\text { No. } \\
{[\mathrm{cm}]}\end{array}$ & $\begin{array}{l}{ }^{14} \mathrm{C} \text { [yr BP] } \\
{[\mathrm{cm}}\end{array}$ & $\begin{array}{l}\text { Calibrated age } \\
{[\text { cal yr BP] }} \\
(95.4 \%)\end{array}$ & $\begin{array}{l}\text { Laboratory } \\
\text { code }\end{array}$ & Dated material \\
\hline 1 & $554-556$ & $9140 \pm 50$ & $10,483-10,220$ & Poz-58614 & Total organic carbon \\
2 & $594-596$ & $11,260 \pm 60$ & $13,262-13,033$ & Poz-58616 & Total organic carbon \\
3 & $630-632$ & $11,210 \pm 60$ & $13,210-12,931$ & Poz-58617 & Total organic carbon \\
4 & $700-702$ & $14,120 \pm 70$ & $17,451-16,940$ & Poz-58619 & Total organic carbon \\
\hline
\end{tabular}

\subsection{Palynological and non-pollen palynomorph records}

Six statistically important LPAZ were established. Description of the LPAZ-S are presented in Table 2 and displayed on the pollen diagram (Fig. 2 A,B). As only scattered pollen grains have been discovered in the lowermost part of the profile $(703-733 \mathrm{~cm})$, no continuous pollen curves were created for this interval. Discussion of non-pollen palynomorphs follows those of pollen and spores.

Table 2

Description of the local pollen assemblage zones.

\begin{tabular}{|c|c|c|}
\hline LPAZ & $\begin{array}{l}\text { Depth } \\
\text { (cm) }\end{array}$ & Description \\
\hline S-1 & $687-703$ & $\begin{array}{l}\text { This zone is marked by high content of Betula (max. 44\%) } \\
\text { pollen and presence of shrubs i.e. B. nana, Alnus sec. } \\
\text { fruticosa, Salix (S. herbacea, S. polaris), Juniperus, Ephedra } \\
\text { distachya. NAP sum shows up to } 16 \% \text { and Artemisia, Poaceae, } \\
\text { Cyperaceae are the best represented. Dryas octopetala, } \\
\text { Selaginella selaginoides and S. helvetica type are noted } \\
\text { sporadically. The value of Pinus attains up to } 60 \% \text { in AP and } \\
\text { Picea shows up to } 1 \% \text {. Pre-Quaternary spores and redeposit } \\
\text { pollen were fixed. The mosses (Bryales) and green algae } \\
\text { (Pediastrum boryanum, P. integrum, P. kawraiskyi) are } \\
\text { discovered. The Glomus spores (host is commonly the roots } \\
\text { of plants) are present in the fungi structure. }\end{array}$ \\
\hline
\end{tabular}

S-2 632-687 The increase of Pinus (to 85\%) and decrease of Betula (4\%) are characteristic for this zone. Picea reaches up to $0.8 \%$. NAP sum decreases to $1 \%$ in the first half of the zone and increases to $17 \%$ afterwards. Single grain of Typha latifolia, T. angustifolia and Myriophyllum recorded. Among the nonpollen palynomorphs a high content of Pinus stomata and Herpotrichia fungi (the host is needles of coniferous trees) spores alongside with the Glomus are revealed. At the beginning of the zone the green and diatom algae are presented sporadically while number of these specimens increased approaching the upper limit of the zone.

S-3 597-632 This zone is characterized by the culmination of NAP reaching more than $38 \%$; Artemisia (up to $31.8 \%$ ), Poaceae (6.5\%) and Chenopodiaceae (up to $4.6 \%$ ) predominate. NAP curve shows the two sharp peaks close to the limits of the zone. Content of AP is varies between $53 \%$ and $60 \%$, Pinus -42-60\%, Betula -5-11\% whereas Picea values increase (up to $5.8 \%$ ) as well as that of Betula nana. Pinus and Picea stomata are presented sporadically. Aquatic taxa (e.g., Myriophyllum and Equisetum) show lowly increase. The number of green algae $(P$. boryanum, $P$. integrum, $P$. kawraiskyi) and diatoms' is the highest. Amoeba fauna appears and is represented by Centropyxis aculeata (prefers the wet mosses and lake detritus) and Arcella catinus type (fresh water and in wet Sphagnum).

S-4 587-597 This zone is determined by changes in the AP/NAP ratio. Trees pollen has increased (AP 90\%) while herbs pollen has decreased (6.6\%). Pinus (76\%) and Betula (15\%) are dominated. Pollen curve of Picea gradually falls to $0.3 \%$. Scattered grains of Ulmus, Alnus, and Corylus were found. The number of green algae decreases and amoeba fauna is presented by Centropyxis aculeata only.

S-5 555-578 Zone was marked by the abundance of Betula pollen, reaching $71 \%$. The Ulmus $(0.6 \%)$ is constantly present, Alnus, Corylus and Quercus sporadically. Green algae are characterized by P. boryanum, amoeba fauna - by Centropyxis aculeata only. 
Table 2 (continued)

\begin{tabular}{lll}
\hline LPAZ & $\begin{array}{l}\text { Depth } \\
(\mathrm{cm})\end{array}$ & Description \\
\hline S-6 & $523-555$ & $\begin{array}{l}\text { In this zone the number of Betula decreased while Pinus, } \\
\text { Q. mixtum (Ulmus, Quercus, Tilia, Fraxinus), Alnus and Corylus } \\
\text { increased. }\end{array}$ \\
\hline
\end{tabular}

\subsection{Diatom record}

According to diatom compositional changes, four local diatom assamblage zones (LDAZ) were distinguished (Fig. 3) identifying 68 different diatom taxa. The diatom flora is poor both in variety of identified species and number of frustules recorded. Moreover, long intervals of the studied sediment sequence were devoid of diatoms or only contained single specimens. The scarcity of the diatom record can be ascribed to a high accumulation rate of mineral particles, possibly causing dispersion of diatoms, or dissolution of diatom frustules due to poor preservation (Amon et al., 2010). The lowermost part of the section (I LDAZ; $730-703 \mathrm{~cm}$ ) is dominated by the species of Fragilaria (up to $80 \%$ ), with high admixtures of redeposited old marine pre-Quaternary specimens i.e. Paralia sulcata, Coscinodiscus and Actinocyclus, reaching 10-20\%. The next zone (II LDAZ; 703-649 cm) is characterized by the scarcity of the diatom record, as the number of identified diatoms is negligible in most samples (from 10 to 100 specimens/sample), with partly dissolved diatom valves including old pre-Quaternary ones. The number and richness of diatoms culminated in the third zone, III LDAZ $(649-597 \mathrm{~cm})$. Here, in addition to the fragilaroids, epiphytic species such as Achnanthes laterostrata, Cocconeis placentula var. lineata and Cymbella ehrenbergii are common. The uppermost part of the section (IV LDAZ; $597-530 \mathrm{~cm}$ ) is very poor in diatoms.

\subsection{Stable isotopes}

The oxygen $\left(\delta^{18} \mathrm{O}\right)$ and carbon $\left(\delta^{13} \mathrm{C}\right)$ isotope analyses were carried out on bulk carbonates from Staroje Lake (Fig. 2A). Throughout the entire system, the $\delta^{18} \mathrm{O}$ values of bulk carbonate varies from $-5.12 \%$ to $-11.30 \%$, and $\delta^{13} \mathrm{C}$ from $-2.63 \%$ to $+7.06 \%$. There is a general relationship between the $\delta^{18} \mathrm{O}$ and $\delta^{13} \mathrm{C}$ records in most of the profile, although a negative correlation occurred between 575 and $600 \mathrm{~cm}$ and below $690 \mathrm{~cm}$. In the lowermost part of the profile, lithological unit 1 , both isotope records show rather constant values. A remarkable drop of $\delta^{18} \mathrm{O}$ was coincident with the base of lithological unit 2, where and alteration from $-6.02 \%$ to $-10.16 \%$ was recorded. Simultaneously, the $\delta^{13} \mathrm{C}$ curve started to increase continuously towards the top of the lithological unit. $\delta^{18} \mathrm{O}$ exhibits a pronounced decreasing trend in the lower half of unit 2 with some recovery in the upper part. The next decline of both curves is coincident with the unit 2/unit 3 transition, especially apparent in the $\delta^{13} \mathrm{C}$ record (from $+7.06 \%$ to $-0.86 \%$ ). Despite a

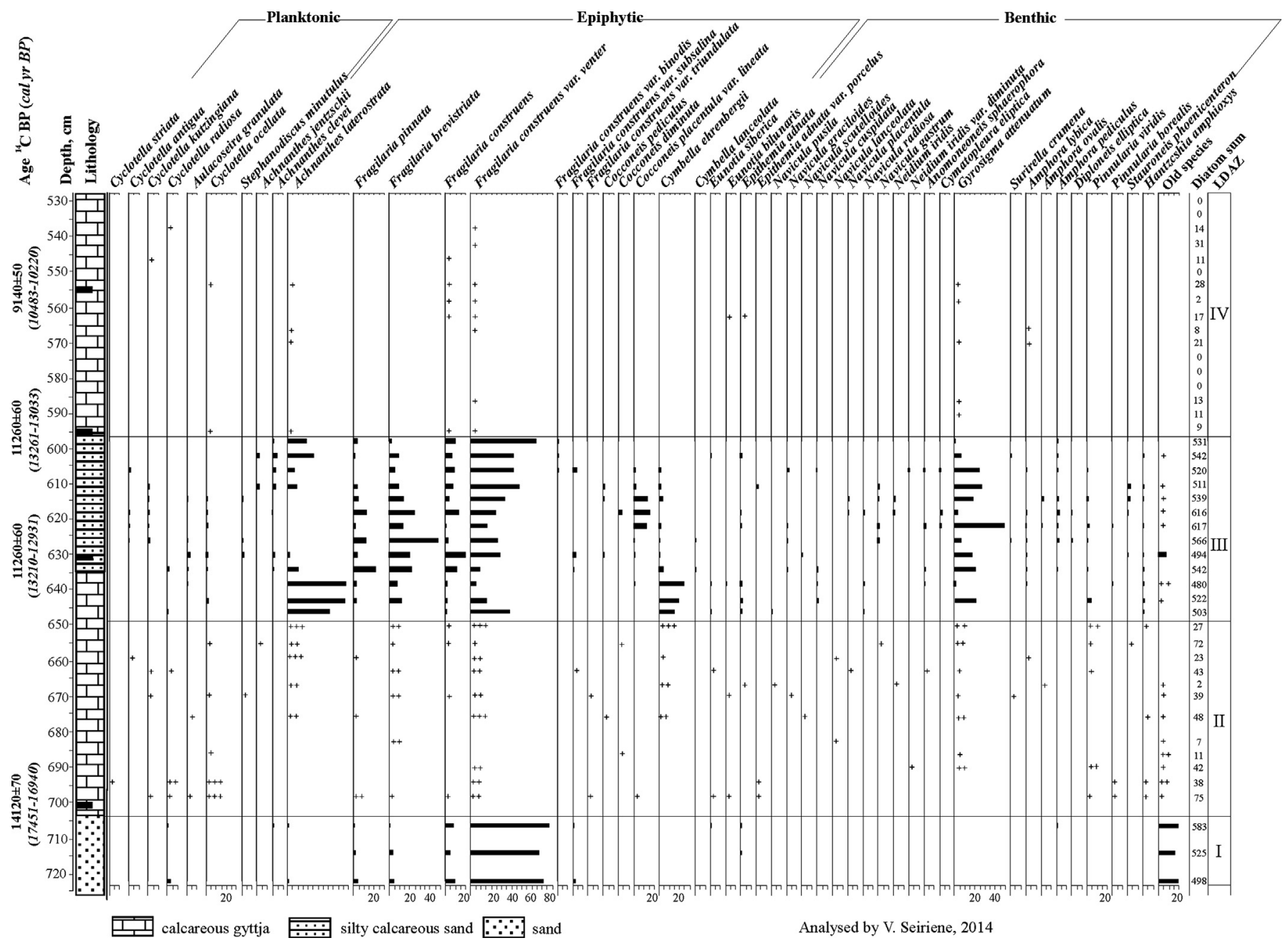

Fig. 3. Percentage diatom diagram of selected taxa for Lake Staroje sediments. 
short-lasting positive excursion recorded in the middle of lithological unit 3, both $\delta^{18} \mathrm{O}$ and $\delta^{13} \mathrm{C}$ contents stay low, varying between $-9.34 \%$ - $-7.43 \%$ and $-1.73 \%$ - $1.30 \%$. Only small variations in $\delta^{18} \mathrm{O}$ values of bulk carbonate are observed in the upper part of the profile $(523-599 \mathrm{~cm})$, while $\delta^{13} \mathrm{C}$ values became more positive in the uppermost part of the investigated interval.

\section{Discussion}

Although the Last Glacial Maximum (Upper Pleniglacial) was dated to 20-17.5 ka BP (Vozniachuk and Valchik, 1978; San'ko, 1987; Karabanov et al., 2004; Marks and Pavlovskaya, 2007) or ca $17.7 \mathrm{ka}\left({ }^{10} \mathrm{Be}\right.$ ages) in Belarus (Rinterknecht et al., 2007) the major part of the territory was still free of ice at that time. The Orsha Moraine and Braslav Moraine formed two moraine belts in northern and northwestern Belarus (Karabanov et al., 2004) suggesting the maximum extent of the ice cover. The remainder of Belarus was a periglacial zone (Markova et al., 2008). The onset of the organic sedimentation in the LG zone (West Dvina basin, between Orsha and Braslav moraine belts) was dated to $15,780 \pm 160{ }^{14} \mathrm{C} \mathrm{BP}$ (18.7-19.3 cal ka BP) (Kalicki et al., 1997) along with the organic enriched deposition in the thermokarst holes that started since approximately $13.0-13.7{ }^{14} \mathrm{C}$ ka BP (Punning et al., 1988; Zernitskaya et al., 2001). In the periglacial zone, deposition in the lacustrine basins started before $12.8{ }^{14} \mathrm{C}$ ka BP (15.0-15.5 cal ka BP) (Matveyev et al., 1993; Zernitskaya et al., 2001, 2010). Although the lack of radiocarbon data does not allow detailed determination of the commencement of biogenic sedimentation in the biggest part of the country, it seems that this process was contemporary with the degradation of the ice cover. The information obtained from Staroje Lake has further described the environmental situation in this part of the periglacial zone.

Based on the obtained information, six environmental stages have been recognized in the record of Staroje Lake. Those allocated for LG are compared with the event stratigraphy proposed by Lowe et al. (2008).

\subsection{Before 14,500 cal BP}

As inferred from the obtained data, limnic sedimentation processes started with the deposition of the grey calcareous gyttja containing little organic matter and detrital carbon in Staroje Lake $(703 \mathrm{~cm}$, Fig. 2A). The underlying yellowish sand (703-733 cm, Fig. 2A) with negligible organic matter (less than $2.2 \%$ ) and $\mathrm{CaCO}_{3}$ (less than $15.7 \%$ ) suggests low productivity of the catchment and intensive input of reworked material. Exhibiting rather constant values of both $\delta^{18} \mathrm{O}_{\text {Carb }}$ and $\delta^{13} \mathrm{C}_{\text {Carb }}$ curves, the stable isotope data suggest rapid formation of the sand bed, very stable climatic and environmental regimes, or, most likely, redeposition of the sediments including Devonian dolomites and Cretaceous limestone widely distributed in the area (Matveyev et al., 1988). In general, the quantitative interpretation of carbonate oxygen-isotope records obtained from small shallow lakes is complicated by many effects (Leng and Marshall, 2004) including strong seasonal and inter-annual variability of the water temperature. The high corrosion of the pollen grains identified in most of the investigated samples supports this assumption confirming instability of the surface. The above conclusion is also supported by the diatom data that contain a large number of redeposited old, marine diatom frustules, especially P. sulcata and fragments of frustules of genus Coscinodiscus, Actinocyclus and others reaching 10-20\% (LDAZ-I, 730-703 cm, Fig. 3). In general, the lowermost part of the section is dominated by the species of Fragilaria genus (up to 80\%), mainly Fragilaria construens spp. and in lesser numbers, Fragilaria brevistriata and Fragilaria pinnata.
There are eurytopic taxa occurring in littoral as well as pelagic biotopes and often found in alkaline, slightly brackish water rich in dissolved mineral salts. Fragilaria spp. reaches an optimum in oxygen-rich waters and often occurs during the initial phase of lake development (Seppä and Weckström, 1999). Flourishing of these taxa may reflect their opportunism, adaptation ability to rapidly changing environments, and high reproductive rate (Lotter et al., 1999; Helmens et al., 2009). Some small cold water species such as A. laterostrata, Amphora pediculus and others are present in this zone as well. The combination of corroborating evidence from palaeobotanical, lithological and isotope analyses indicate that terrigenous sedimentation predominated during the initial phase of the lake development that could be related with the disappearance of permafrost and formation of sedimentary basins. Recorded events could be attributed to the end of the Pleniglacial or GS-2 event (Greenland Stadial - 2 event, according to Lowe et al., 2008).

An onset of S-1 pollen zone (Fig. 2 A,B) is coincident with remarkable changes recorded in all investigated proxies i.e. isotope record, loss-on-ignition data, and diatom spectra. $\delta^{18} \mathrm{O}$ exhibits a pronounced decreasing trend at the onset of the LPAZ, where the pollen data suggest a rather mild environmental regime with increasing density of vegetation cover. Low values of $\delta^{18} \mathrm{O}$ could be related to the intensive input of isotope signal from the glacial epoch connected with the disintegration of permafrost and inflow of ancient cold water into the basin. This is also supported by the presence of pre-Quaternary spores and pollen in spectra. In the pollen diagram from Staroje Lake, the recorded value of birch (exceeding 20\%), most likely Betula nana, indicates local growth of this plant. Moreover, the presence of Pinus stomata confirms proximity of the pine stands, and local origin of the identified pollen grains. In fossil pollen records, percentage values that have been used as an indicator of local growth of pine vary between $20 \%$ in England (Bennett, 1984), 25\% in Poland (Latałowa et al., 2004), and 55\% in Norway (Barnett et al., 2001). Thus, the recorded amount of Pinus pollen (39-60\%) in the lower part of Staroje Lake suggests the local presence of this tree as well. Refuges of forest vegetation in LGM existed in the Podolian region, central Russian Uplands, as well as in valleys of the Dniester and Dnieper (Ukrainian part) rivers (Markova et al., 2008), that are relatively close to the region under investigation, supporting early establishment of the taxa in the area. Full-glacial survival of numerous tree species during the LGM in northerly refugia including Central and Eastern Europe was confirmed by genetic evidence as well (Willis and van Andel, 2004). As the critical mean July temperature limits for the flowering of Pinus and Betula are $12{ }^{\circ} \mathrm{C}$ and $13{ }^{\circ} \mathrm{C}$ respectively (Huusko and Hicks, 2009; Kuoppamaa et al., 2009), climatic regime was rather favorable. The changes of the oxygen-isotope rate could be related with an increase in the evaporation regulated by the changes in the air humidity and an increase in the relative portion of detrital carbonate (Hammarlund and Buchard, 1996; Böttger et al., 1998). In Staroje Lake, increasing input of detrital carbon particles could result from the Devonian and Carboniferous carbonenriched formations common in the area (Matveyev et al., 1988), and the amount of $\mathrm{CaCO}_{3}$ increased remarkably within the S-1 pollen zone. Intensive discharge of the ground water causing transportation of detrital carbon into the basin is highly possible, along with development of karst processes. As high carbonate content positively influences diatom dissolution (Lewin, 1961; Barker et al., 1994) minor representation of the diatom shells in the sediments (LDAZ II, Fig. 3) may be explained on this basis as well. Partly dissolved diatom valves, mainly of Cocconeis and Cyclotella, were recorded in some levels, and benthic i.e. Fragilaria spp., A. laterostrata, Epithemia adnata, Gyrosigma attenuatum, and Pinnularia viridis recognized. Old pre-Quaternary diatom frustules 
and their fragments remains are numerous, suggesting transportation of the old material into the basin.

The final stages of the Upper Pleniglacial are also characterised by the deposition of the calcareous gyttja in Staroje Lake. At the same time, this transition is distinct in the pattern of plant communities. The most characteristic features of this period are the presence of dwarf birch (B. nana) and willows (e.g. Salix herbacea, Salix polaris), Alnus sec. fruticosa, Juniperus, Ephedra distachya, together with Dryas octopetala, Selaginella selaginoides and Bryales moss. The indicators of drier soil were Chenopodiaceae and Artemisia. Based on ecological studies, green algae i.e. Pediastrum kawraiskyi, Pediastrum integrum, Pediastrum boryanum, and Botryococcus terribilis occur in small, cold carbonate enriched oligodystrophic water basins or in those surrounded by communities of mosses (Jankovská and Komárek, 2000). The vegetation at the end of the Pleniglacial (GS-2/GI-1e transition sensu Lowe et al., 2008) is characterised by mosaic combinations of shrub tundra and foresttundra landscapes with sites of steppe plants on unstable mineral soils. According to Markova et al. (2008), during the LGM similar vegetation was widespread between $53^{\circ}$ and $56^{\circ} \mathrm{N}$, while between 49 and $53^{\circ} \mathrm{N}$ the role of steppe landscapes increased.

\section{2. $14,500-13,100 \mathrm{cal} \mathrm{BP}$}

Clear signs of pronounced amelioration of environmental conditions occurred in most proxies of Staroje Lake after 14,500 cal BP. The environmental shift was correlated with the Bölling warming (Greenland Interstadial-1e event), which was as warm as today according to different proxy records (O'Connell et al., 1999). Rising values of both $\mathrm{OM}$ and $\mathrm{CaCO}_{3}$ suggest increasing richness of the limnic and terrestrial environment. The recorded strong increase in carbon content is likely to mark the onset of authigenic carbon precipitation. Most probably, input of detrital carbon into the lake decreased as the amount of terrigenous matter decreased remarkably. Predominance of autochthonous carbonates is also confirmed by the diatom record, where the number and quality of identified specimens increased, as epiphytic species as A. laterostrata, $C$. placentula var. lineata and $C$. ehrenbergii flourished in the lower part of LDAZ-III (630-650 cm, Fig. 3). Generally, the water level was low at that time, and Typha latifolia, Typha angustifolia, Myriophyllum and Equisetum occupied the littoral zone of the lake. High representation of warm water preferring species of diatom algae such as C. ehrenbergii and Anomoneoneis sphaerophora was favored by the changes of the thermal regime of the basin. Considerable changes of the $\delta^{13} \mathrm{C}$ curve that started at the onset of the interval indicate greater photosynthetic activity in the lake, giving rise to $\delta^{13} \mathrm{C}$-enrichment of the DIC (dissolved inorganic carbon) (McKenzie, 1985) and pointing to increasing lacustrine productivity. A positive correlation between oxygen and carbon stable isotopic compositions is observed in closed lakes systems (Turner et al., 1983) suggesting termination of water inflow to Staroje Lake during the second half of the period under consideration, correlated with Alleröd warming.

In our record, this time interval is manifested as a culmination of a Pinus sylvestris curve $(630-687 \mathrm{~cm})$ suggesting flourishing of the pine dominant forest, while birch vanished simultaneously. Pine stomata and fungi (Glomus, Herpotrichia) are present, constantly indicating the proximity of the shoreline to the coring point. At the end of this time interval, the role of herbaceous vegetation and spruce in pollen spectra started to increase. Gradual immigration of spruce into the region occurred. Fossil pollen records varying between 1\% (Tantau et al., 2006) and 5\% (Huntley and Birks, 1983) were used as a threshold to track the spread of this tree in different parts of Europe (Lisitsyna et al., 2011). The beginning of the continuous curve was taken as the indicator of the local presence of this tree (Giesecke and Bennett, 2004; Savelieva, 2007). However, in our record the Picea curve varies from $0.2 \%(654 \mathrm{~cm})$ to $0.6 \%$ $(634 \mathrm{~cm}$ ) (see Fig. 2B), suggesting only the regional presence of spruce approaching the end of the Lateglacial Interstadial. Vegetation of the Interstadial is characterized by birch-pine, pine and spruce forests in the western part of European Russia (Moscow and Central Russian Uplands) (Gerasimov and Velichko, 1982; Velichko et al., 1997; Wohlfarth et al., 2007; Markova et al., 2008; Novenko et al., 2009).

\section{3. $13,100-11,700 \mathrm{cal} \mathrm{BP}$}

Following the distinct decrease in $\delta^{18} \mathrm{O}$ curve at the LPAZ S-2/S-3 transition, a positive shift was recorded within zone LPAZ S-3, suggesting remarkable changes in the environmental regime (Fig. 2B). Both chronological and biostratigraphical attribution suggests that this interval can be associated with GS-1 event (Lowe et al., 2008) or Younger Dryas cooling. Lithological composition exhibits a remarkable rise of the terrigenous component (Fig. 4), indicating intensive catchment erosion and material inwash into the basin. That is especially obvious in the first half of the interval (633-617 cm) when OM is less than $10 \%$ in particular samples and $\mathrm{CaCO}_{3}$ varies around approximately $10 \%$ (Fig. 2A). The low $\mathrm{CaCO}_{3}$ makes the interpretation of the $\delta^{18} \mathrm{O}$ and $\delta^{13} \mathrm{C}$ records rather debatable, as detrital carbon predominates in the record, most likely due to high erosion activity. The recorded excursion of isotope curves may be related with the positive changes of the temperature followed by the aridification of the climatic regime in the middle of pollen zone S-3 $(612 \mathrm{~cm}$, Fig. 2 A,B). The clearly expressed alteration of silty and sandy layers recorded between 610 and $618 \mathrm{~cm}$ indicates seasonality of sediment formation (Fig. 4). Subsequently, water level in the lake lowered. The similar pattern of the $\delta^{18} \mathrm{O}$ record leading to the positive climatic shift comparable with the middle part of the Younger Dryas was recorded in different European lakes (Schwander et al., 2000; Jones and Marshall, 2002; Makhnach et al., 2004, 2009). Alongside with the lithological and isotope data, the regional multi-proxy records indicate the first part of the Younger Dryas (633-618 cm) was especially dry and cold, followed by a period of rising humidity and temperature (Goslar et al., 1999; Veski et al., 2012).

In Belarus, this time period is characterized by the decreasing representation of Pinus concurrent with the rising number of Picea and non-arboreal pollen (NAP) in northern and central regions particularly (Zernitskaya et al., 2001, 2005; Makhnach et al., 2004). A similar pattern of vegetation structure was recorded in the Staroje Lake sequence. Discovered in the upper part of the interval, 605-610 cm, stomata of Pinus and Picea mark the presence of these trees in the local vegetation. The lack of Pinaceae stomata and fungi during the initial stages of the Younger Dryas sedimentation could be related to the recession of these trees from the closest vicinities of the lake. The distance between the coring site and the lake shore could have influenced dispersal and deposition of these remains as well. Pollen data suggest relatively high density of spruce, whereas $B$. nana and $A$. sec. fruticosa were represented sporadically. The drop of the mean temperature recorded all around Europe at the beginning of GS-1 Stadial may have caused the episodic occurrence of the permafrost in particular areas of Eastern Europe (Velichko et al., 1997; Gerasimenko, 2006; Dzieduszyńska and Petera-

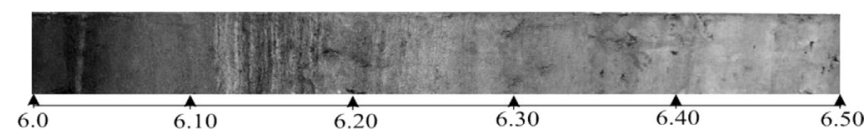

Fig. 4. Lithological column of the Staroe Lake (GS-1- 6.0-6.33 m, GI-1c- 6.33-6.50). 
Zganiacz, 2012; Dzieduszyńska et al., 2014). The climatic regime as well as the environmental situation supported the spread of spruce in the region and the number of Picea pollen increased from $1.2 \%$ $(626 \mathrm{~cm})$ to $5.8 \%(598 \mathrm{~cm})$ in the pollen diagram of Staroje Lake (Fig. 2B). The rise of the Picea curve was dated to 13,200-12,780 cal BP in the central region of Belarus (Bogdel et al., 1983; Makhnach et al., 2009). This tree migrated to Northern Belarus during the Younger Dryas. The Picea obovata cone from alluvial deposits of the Luchosa River (W. Dvina basin, NE Belarus) was dated to $10,650 \pm 160{ }^{14} \mathrm{C}$ BP $(12,736-12,265$ cal BP) (San'ko, 1987). Increase of spruce pollen values in the sediments of Lake Naroch (NW Belarus) are confirmed by the $10,710 \pm 50{ }^{14} \mathrm{C}$ BP (12,736-12,265 cal BP) age (Yakushko and Makhnach, 1973; Punning et al., 1988), and in the central region of the country at $10,920 \pm 90{ }^{14} \mathrm{C}$ BP $(12,980-12,774$ cal BP) (Zernitskaya et al., 2005; Makhnach et al., 2009). Although the post-Glacial history of spruce in Europe has been under discussion for a decade (Giesecke and Bennett, 2004; Giesecke, 2005a,b; Latałowa and van der Knaap, 2006), the earliest post-Glacial history of this tree in particular areas of the continent, including Eastern Europe, is still unknown. The Middle Russian Upland and East European Plain as well as Alpine forelands and Danubian plain have been indicated as possible refuge areas for this tree during the Late Weichselian Glaciation (Zernitskaya, 1995; Terhürne-Berson, 2005; Latałowa and van der Knaap, 2006). Lateglacial occurrence of Picea sp. needles and seeds was noticed in southeastern and western Lithuania and southeastern Latvia (Stančikaitè et al., 2008; Heikkilä et al., 2009). Palynological evidence and presence of plant macrofossils (seeds and needles) suggests early Holocene immigration of Picea sp. to northeastern Lithuania (Stančikaitè et al., 2004, 2009). Even in Scandinavia, spruce arrived in the Lateglacial and early Holocene (Kullman, 2000; Segerström and von Stedingk, 2003; Giesecke, 2004). The presence of Picea suggests that a continental climate with warm summers $\left(\sim+10^{\circ} \mathrm{C}\right)$ and moist soil conditions (Giesecke and Bennett, 2004) predominated in southeastern Belarus in the second half of 13,100-11,700 cal BP interval, especially. The simultaneous increase of Artemisia and spread of Picea during the Younger Dryas cooling may be connected with increasing intensity of erosional processes (Artemisia, Chenopodiaceae) and reestablished permafrost (considering the linear root system of spruce). Undoubtedly, pine formed a part of the forest on sandy soil that persisted throughout $13,100-11,700$ cal BP. Generally, the vegetation of the YD cooling was represented by light pine forests with birch and spruce, in combination with herb-grass-shrubs communities. Deposition of investigated sediments took place in the littoral shallow zone of the lake, where benthic species of amoebae such as Centropyxis aculeata and Arcella catinus typical in the boggy habitats (Rhizopoda curve) (Bobrov et al., 1999; Booth, 2002; Lamentowicz et al., 2008) flourished. Predominance of epiphytic and benthic diatom species i.e. G. attenuatum and $P$. viridis suggests a shallow sedimentary environment as well.

\section{4. $11,700-11,500$ cal BP}

After 11,700 cal BP, changes of the environmental regime started in the surroundings of Staroje Lake. These are reflected in the lithological transition from dark grey silty calcareous sand to light grey calcareous gyttja, suggesting gradual stabilisation of the sedimentation regime. The contemporaneous strong increase in $\mathrm{CaCO}_{3}$ content is likely to mark the onset of authigenic carbonate precipitation, while the catchment biota was still poor as indicated by the low amount of $\mathrm{OM}$ in comparison with the previous cold interval. Both $\delta^{18} \mathrm{O}$ and $\delta^{13} \mathrm{C}$ curves remain rather stable, and this pattern of the isotope records could be associated with permafrost degradation (Velichko et al., 1997) followed by meltwater discharge into the basin. Old carbon may have played a role in the $\delta^{18} \mathrm{O}$ record as well. The abrupt rise of the carbon content suggests increasing richness of the lacustrine environment. The short-term episode of active permafrost caused a rise of lake level followed by the rapid fall or stabilisation of the water table. This event was well documented in the reduction of green algae and disappearance of benthic amoebae (Fig. 2B). Aquatic vegetation is characterised by the episodic presence of T. latifolia. Recurring rise of the carbonate content may have positively influenced dissolution of the diatom frustules (Lewin, 1961; Barker et al., 1994), as only negligible representation of these were recorded in most investigated samples (Fig. 3). Nonetheless, the specimens confirm low water table in the basin. Similar extraordinary low lake-levels were recorded over large parts of Europe during the earliest stages of the Holocene (Gaillard, 1985; Bohncke and Wijmstra, 1988; Kabailienè, 1993; Makhnach et al., 2000; Wohlfarth et al., 2006). Furthermore, decreasing moisture regime is also confirmed by the reduction of spruce and simultaneous development of pine thickets (LPAZ S-4, Fig. 2B). In the northern part of the periglacial zone of Belarus, an abrupt reduction of spruce was revealed at approximately 11,600 cal BP (Zernitskaya, 1995; Zernitskaya and Mikhailov, 2009; Novik et al., 2010). In the surroundings of Staroje Lake, reforestation was accompanied by the first signals of thermophilous trees such as Ulmus and Alnus established on the regional scale. This interval could be interpreted as a transitional zone between the Lateglacial and Early Holocene.

\section{5. $11,500-9,500$ cal BP}

The onset of the Early Holocene is marked by distinct vegetation changes in the investigated profile. Pollen evidence (zone S-5, Fig. 2B) suggests flourishing of the open Betula dominated forest with a negligible proportion of Pinus until approximately 10,300 cal BP, when Ulmus and later Alnus slowly penetrated the area. Flourishing of open birch forest during the initial stages of the Holocene was marked in this part of Eastern Europe (Zernitskaya, 1995; Ralska-Jasiewiczowa et al., 2004; Kabailiené, 2006). Small open habitats persisted on the lake shores, most likely, as the number of herbs and grasses remained minor in the pollen record. Aquatic taxa are represented by T. latifolia, T. angustifolia, Myriophyllum, the green algae by $P$. boryanum, and that of amoeba fauna by $C$. aculeata. Eutrophication level in the lake increased. Although the value of OM remains low in the sediments, increasing content of $\mathrm{CaCO}_{3}$ suggest formation of a rich lacustrine environment. Autochthonous carbonates predominated in the sediments, as inflow of eroded material was minor according to the LOI data. The rather stable values of $\delta^{18} \mathrm{O}$ (Fig. 2A) suggest that there were steady-state conditions in terms of evaporative enrichment in $\delta^{18} \mathrm{O}$ (Lister et al., 1991) until approximately 11,000-10,800 cal BP. Within the mentioned time interval, the negligible decline in both the $\delta^{18} \mathrm{O}$ and $\delta^{13} \mathrm{C}$ values was recorded, indicating some instability in terms of temperature and moisture. Biological productivity declined at the same time. Based on numerous different proxies, several early Holocene environmental shifts were identified and described in different parts of Europe (Ammann et al., 2000; Nesje et al., 2004; Andresen et al., 2007; Bohncke and Hoek, 2007) including the Baltic region (Stančikaite et al., 2009). The most prominent climate deterioration, termed the Preboreal Oscillation (PBO) and dated to 11,300-11,150 cal BP, has been described as a humid and cool interval in northwestern and central Europe (Björck et al., 1997). According to Fisher et al. (2002) the Preboreal oscillation led to increase in pack ice on the North Atlantic Ocean that lowered surface temperatures, increased albedo, and likely forced changes in ocean circulation (Diefendorf et al., 2006). Data obtained from Staroje Lake in SE Belarus indicate some climatic and 
environmental shifts during the early Holocene. These became especially pronounced between 10,300 cal BP and 9,500 cal BP, when increasing terrigenous input suggests rising water inflow into the basin. At the same time, organic richness of the sediments became higher in positive correlation with the pollen record, confirming the formation of a mixed thermophilous forest with deciduous trees including Tilia, Quercus, Alnus, and Corylus. The sudden rise of $\delta^{18} \mathrm{O}$ and $\delta^{13} \mathrm{C}$ records was punctuated by a subsequent drop, suggesting both hydrological and climatic fluctuations. In northern and northwestern Europe, several cool oscillations centered on the Preboreal have been determined through various palaeoenvironmental records (Velichko et al., 1997; Wastegård, 1998; Björck and Wastegård, 1999; Magny et al., 2007). Changes in melt water supply to the North Atlantic forced changes in oceanic and atmospheric circulation (Andrews et al., 1991) initiating instability (Diefendorf et al., 2006).

Recent investigations indicate the correlation between palaeoenvironmental variations representing the North Atlantic region and the eastern part of Europe. Further multi-proxy investigations providing independent chronological framework, and palaeoclimatic reconstructions are needed for this region to extend our knowledge about the Lateglacial history in the eastern part of Europe.

\section{Conclusions}

The results of the multi-proxy investigations carried out in Staroje Lake, SE Belarus, situated outside the maximum extent of the Scandinavian Ice Sheet, provide information concerning the Lateglacial-Early Holocene environmental history, including vegetation pattern, water level fluctuations, and local climatic and hydrological variations between 14,500 and 9,500 cal BP. The obtained results suggest the following conclusions:

- In Staroje Lake, sedimentation processes recommenced in response to degradation of the permafrost and occurrence of the karst pond. Shortly before 14,500 cal BP, i.e. at the end of the Pleniglacial (GI-2), deposition of the calcareous gyttja in the basin started, suggesting improvement of environmental regime including climatic amelioration as indicated by formation of shrub and forest-shrub tundra with the predominance of $B$. nana and the local presence of Pinus stands.

- During the Lateglacial Interstadial (GI-1), open Pinus dominated forest flourished between 14,500 and 13,100 cal BP in the surroundings of the lake where the water table stayed relatively low, as documented by the diatom record. Predominance of autochthonous carbon confirms increasing productivity of the sedimentary basin, also indicated by high OM content. The parallel increases in $\delta^{18} \mathrm{O}$ and $\delta^{13} \mathrm{C}$ records suggest formation of a closed lake system after 13,300-13,200 cal BP.

- Both palaeobotanical and isotope data exhibit simultaneous negative excursions of the climatic regime, that may have triggered the episodic occurrence of permafrost and increasing groundwater level at the transition from Lateglacial Interstadial to the GS-1 Stadial. Drop of the organic and carbon productivity was coincident with the increasing erosion activity, determining the intensive inflow of detrital material into the shallow water basin at the beginning of the interval. Climatic deterioration brought about the formation of forest-tundra (Pinus, B. nana) vegetation in combination with herbs (Artemisia, Chenopodiaceae). Wet soils created conditions for the penetration of Picea stands that became important component of the local vegetation. The positive changes of the isotope records at approximately $12,300-12,400$ cal BP suggest a reversal to warmer conditions during the next part of the stadial.
- Changes in the lithological record indicate the initial stages of the environmental improvement since approximately 11,700 cal BP onward. The sudden rise of the carbon content suggests increasing richness of the lacustrine environment, while the reaction of the terrestrial environmental was rather moderate. The last episode of active permafrost decay as well as the gradual rise of the thermal regime and decreasing humidity may have played a leading role in the extinction of spruce at the Lateglacial/Holocene transition. Open pine dominated forest with some admixture of birch dominated the territory. Changes of the biological productivity, $\delta^{18} \mathrm{O}$ and $\delta^{13} \mathrm{C}$ records, and lithological composition of the strata indicate some climatic and environmental shifts in the area during the Early Holocene and became especially pronounced between 10,300 cal BP and 9,500 cal BP. Centered around the Preboreal, these were correlated with the Early Holocene climatic variations widely recorded all around western Europe. The original data obtained from Staroje Lake, SE Belarus, show some degree of correlation between environmental and climatic variations representing the North Atlantic region and the eastern part of Europe.

\section{Acknowledgments}

Dr. N. Makhnach (Belarus) is acknowledged for the valuable discussion on isotope data and numerous important advises discussing environmental history in this part of Europe. We also thank A. Glas from laboratory of Geodynamics and Palaeogeography (Institute for Nature Management) for his help in the field. This study was financed by the Research Council of Lithuania (No. LEK08/2012) and the Belarusian State Foundation of Fundamental Investigations (Grant XMC13-002).

\section{Appendix A. Supplementary data}

Supplementary data related to this article can be found at http:// dx.doi.org/10.1016/j.quaint.2014.06.045.

\section{References}

Amon, L., Heinsalu, A., Veski, S., 2010. Late glacial multiproxy evidence of vegetation development and environmental change at Solova, southeastern Estonia. Estonian Journal of Earth Sciences 59 (2), 151-163.

Ammann, B., Birks, H.J.B., Brooks, S.J., Eicher, U., von Grafenstein, U., Hoffman, W. Lemdahl, G., Schwander, J., Tobolski, K., Wick, L., 2000. Quantification of biotic responses to rapid climate changes around the Younger Dryas - a synthesis. Palaeogeography, Palaeoclimatology, Palaeoecology 159, 313-347.

Ammann, B., von Grafenstein, U., van Raden, U.J., 2013a. Biotic responses to rapid warming about $14,685 \mathrm{yr}$ BP: introduction to a case study at Gerzensee (Switzerland). Palaeogeography, Palaeoclimatology, Palaeoecology 391, 3-12.

Ammann, B., van Leeuwen, J.F.N., van der Knaap, W.O., Lischke, H., Heiri, O. Tinner, W., 2013b. Vegetation responses to rapid warming and to minor climatic fluctuations during the Late-Glacial Interstadial (GI-1) at Gerzensee (Switzerland). Palaeogeography, Palaeoclimatology, Palaeoecology 391, 40-59.

Andrews, J.T., Erlenkeuser, H., Evans, L.W., Briggs, W.M., Jull, A.J.T., 1991. Meltwater and deglaciation, SE Baffin Shelf (NE margin Laurentide ice sheet) between 13 and $7 \mathrm{ka}$ : from $\mathrm{O}$ and $\mathrm{C}$ stable isotopic data. Palaeoceanography 6, 621-637.

Andresen, C.S., Björck, S., Jessen, C., Rundgren, M., 2007. Early Holocene terrestrial climatic variability along a North Atlantic Island transect: paleoceanographic implications. Quaternary Science Reviews 26, 1989-1998.

Barker, P., Fontes, J.C., Gasse, F., Druart, J.C., 1994. Experimental dissolution of diatom silica in concentrated salt solutions and implications for palaeoenvironmental reconstruction. Limnology and Oceanography 39, 99-110.

Barnett, C., Dumayne-Peaty, L., Matthews, J.A., 2001. Holocene climatic change and tree-line response in Leirdalen, central Jotunheimen, south central Norway. Review of Palaeobotany and Palynology 117, 119-137.

Battarbee, R.W., 1986. Diatom analysis. In: Berglund, B.E. (Ed.), Handbook of Holocene Palaeocology and Palaeohydrology. Wiley, Chichester, New York, pp. 527-570.

Bennett, K.D., 1984. Post-glacial history of Pinus sylvestris in the British Isles. Quaternary Science Reviews 3, 133-155.

Berglund, B.E., Ralska-Jasiewiczowa, M., 1986. Pollen analysis and pollen diagrams. In: Berglund, B.E. (Ed.), Handbook of Holocene Palaeoecology and Palaeohydrology. Wiley, Chichester, p. 483. 
Binney, H.A., Willis, K.J., Edwards, M.E., Bhagwat, S.A., Anderson, P.M., Andreev, A.A., Blaauw, M., Damblon, F., Haesaerts, P., Kienast, F., Kremenetski, K.V., Krivonogov, S.K., Lozhkin, A.V., MacDonald, G.M., Novenko, E.Y., Oksanen, P., Sapelko, T.V., Väliranta, M., Vazhenina, L., 2009. The distribution of late Quaternary woody taxa in northern Eurasia: evidence from a new macrofossil database. Quaternary Science Reviews 28, 2445-2464.

Birks, H.J.B., Birks, H.H., 2004. The rise and fall of forest. Science 305, 484-485.

Birks, H.J.B., Willis, K.J., 2008. Alpines, trees, and refuge in Europe. Plant Ecology \& Diversity 1, 147-160.

Björck, S., Rundgren, M., Ingölfsson, O., Funder, S., 1997. The Preboreal oscillation around the Nordic Seas: terrestrial and lacustrine responses. Journal of Quaternary Science 12, 455-465.

Björck, J., Wastegård, S., 1999. Climate oscillations and tephrochronology in eastern middle Sweden during the last glacial-interglacial transition. Journal of Quaternary Science 14, 399-410.

Bobrov, A.A., Charman, D.J., Warner, B.G., 1999. Ecology of testate amoebae (Protozoa: Rhizopoda) on peatlands in western Russia with special attention to niche separation in closely related taxa. Protist 150, 125-136.

Bogdel, I.I., Vlasov, B.P., Ilves, E.O., Klimanov, B.A., 1983. Sudoble section - stratotype reconstruction of palaeogeographical conditions of Holocene of Central Belarus. In: Raukas, A., Saarse, L. (Eds.), History of Lakes in the USSR, Tallinn, T. 1, pp. 30-32 (in Russian).

Bohncke, S., Wijmstra, L., 1988. Reconstruction of late-glacial lake-level fluctuations in the Netherlands based on palaeobotanical analyses, geochemical results and pollen density data. Boreas 17, 403-425.

Bohncke, S.J.P., Hoek, W.Z., 2007. Multiple oscillations during the Preboreal as recorded in a calcareous gyttja, Kingbeekdal, The Netherlands. Quaternary Science Reviews 26, 1965-1974.

Booth, R.K., 2002. Testate amoebae as paleoindicators of surface-moisture changes on Michigan peatlands: modern ecology and hydrological calibration. Journal of Paleolimnology 28, 329-348.

Böttger, T., Hiller, A., Junge, F.W., Litt, T., Mania, D., Scheele, N., 1998. Late Glacial stale isotope record, radiocarbon stratigraphy, pollen and mollusk analyses from the Geiseltal area, Central Germany. Boreas 27, 88-100.

Bronk Ramsey, C., Dee, M., Lee, S., Nakagawa, T., Staff, R., 2010. Developments in the calibration and modelling of radiocarbon dates. Radiocarbon 52 (3), 953-961.

Brooks, S.J., Birks, H.J.B., 2000a. Chironomid-inferred late-glacial and earlyHolocene mean July air temperatures for Kråkenes Lake, western Norway. Journal of Paleolimnology 23, 77-89.

Brooks, S.J., Birks, H.J.B., 2000b. Chironomid-inferred Late-glacial air temperatures at Whitrig Bog, southeast Scotland. Journal of Quaternary Science 15, 759-764.

Diefendorf, A.F., Patterson, W.P., Mullins, H.T., Tibert, N., Martini, A., 2006. Evidence for high-frequency late Glacial to mid-Holocene (16,800 to 5500 cal yr B.P.) climate variability from oxygen isotope values of Lough Inchiquin, Ireland. Quaternary Research 65, 78-86.

Dzieduszyńska, D., Petera-Zganiacz, J., 2012. Geologic position of the Younger Dryas subfossil forest in the Warta River Valley, central Poland. Bulletin of the Geological Society of Finland 84, 69-79.

Dzieduszyńska, D., Kittel, P., Petera-Zganiacz, J., Brooks, S., Korzeń, K., Krąpiec, M., Paw1owski, D., P1aza, D., Płóciennik, M., Stachowicz-Rybka, R., Twardy, J., 2014 Environmental influence on forest development and decline in the Warta River valley (Central Poland) during the Late Weichselian. Quaternary International 324, 99-114.

Erdtman, G., 1936. New method in pollen analysis. Svensk Botanisk Tidskrift 30, $154-164$.

Fisher, T.G., Smith, D.G., Andrews, J.T., 2002. Preboreal oscillation caused by a glacial Lake Agassiz flood. Quaternary Science Reviews 21, 873-878.

Gaillard, M.J., 1985. Late-glacial and Holocene environments of some ancient lakes in the western Swiss Plateau. Dissertationes Botanicae 87, 273-336.

Gerasimenko, N., 2006. Upper Pleistocene loess-palaeosol and vegetational successions in the Middle Dnieper Area, Ukraine. Quaternary International 149, $55-66$.

Gerasimov, I.P., Velichko, A.A., 1982. Paleogeography of Europe During the Last 100,000 Years (Atlas-Monograph). Nauka, Moscow, p. 156 (in Russian).

Giesecke, T., 2004. The Holocene Spread of Spruce in Scandinavia (Ph. D. thesis). Uppsala University, Uppsala, 46 pp.

Giesecke, T., 2005a. Moving front or population expansion: how did Picea abies (L.) Karst. become frequent in central Sweden? Quaternary Science Reviews 24, 2495-2509.

Giesecke, T., 2005b. Holocene dynamics of the southern boreal forest in Sweden. The Holocene 15, 858-872.

Giesecke, T., Bennett, K.D., 2004. The Holocene spread of Picea abies (L.) Karst. in Fennoscandia and adjacent areas. Journal of Biogeography 31, 1523-1548.

Goslar, T., Bałaga, K., Arnold, M., Tisnerat, N., Starnawska, E., Kuźniarski, M., Chróst, L., Walanus, A., Więckowski, K., 1999. Climate-related variations in the composition of the Lateglacial and Early Holocene sediments of Lake Perespilno (eastern Poland). Quaternary Science Reviews 18, 899-911.

Grimm, E.C., 1992. Tilia and Tilia graph: pollen spreadsheets and graphics programs. In: 8th International Palynological Congress: Program and Abstracts, Aix-enProvence, France, p. 56.

Grimm, E.C., 2007. Tilia Version 1.0.1. Illinois State Museum, Research and Collections Center, Springfield.

Hammarlund, D., Buchard, B., 1996. Composite stable isotopes records from a Late Weichselian lacustrine sequence at Grænge, Lolland, Denmark: evidence of Allerød and Younger Dryas environments. Boreas 25, 8-22.
Heikkilä, M., Fontana, S., Seppä, H., 2009. Rapid Lateglacial tree population dynamics and ecosystem changes in the eastern Baltic region. Journal of Quaternary Science 24, 802-815.

Helmens, K.F., Risberg, J., Jansson, K.N., Weckström, J., Berntsson, A., Kaislahti Tillman, P., Johansson, P.W., Wastegård, S., 2009. Early MIS 3 glacial lake evolution, ice-marginal retreat pattern and climate at Sokli (northeastern Fennoscandia). Quaternary Science Reviews, 1-15.

Huntley, J., Birks, H.J.B., 1983. An Atlas of Past and Present Pollen Maps for Europe: 0-13,000 Years Ago. Cambridge University Press, Cambridge, p. 138.

Huusko, A., Hicks, S., 2009. Conifer pollen abundance provides a proxy for summer temperature: evidence from the latitudinal forest limit in Finland. Journal of Quaternary Science 24, 522-528.

Jankovská, V., Komárek, J., 2000. Indicative value of Pediastrum and other coccal green algae in palaeoecology. Folia Geobotanica 35, 59-82.

Jones, R.T., Marshall, J.D., 2002. Lacustrine oxygen isotopic records from temperate marl lakes. PAGES News 10 (2), 17-19.

Kabailiene, M., 1993. The problems of stratigraphy and environmental history during Late-Glacial and Holocene in Lithuania. Geologija 14 (2), 208-222.

Kabailienè, M., 2006. Late Glacial and Holocene stratigraphy of Lithuania based on pollen and diatom data. Geologija 54, 42-48.

Kalicki, T., San'ko, A.F., Zernitskaya, V.P., Litvinjuk, G.I., 1997. Evolution of the Zapadnaya Dvina valley on Surazh Plain during the Late Glacial and Holocene. In: Kalicki, T. (Ed.), Study of the Evolution of River Valleys in Belarus - I. Wroclaw, pp. 13-52 (in Polish).

Karabanov, A.K., Matveyev, A.V., Pavlovskaya, I.E., 2004. The main glacial limits in Belarus. In: Ehlers, J., Gibbard, P.L. (Eds.), Quaternary Glaciations - Extent and Chronology. Part I: Europe. Elsevier, Amsterdam, pp. 15-18.

Krammer, K., Lange-Bertalot, H., 1988. Bacillariophyceae. 2. Teil: Bacillariaceae, Epithemiaceae, Surirellaceae. In: Ettl, H., Gerloff, J., Heynig, H., Mollenhauer, D. (Eds.), Süßwasserflora von Mitteleuropa 2/2. Gustav Fischer Verlag, Stuttgart, p. 596.

Krammer, K., Lange-Bertalot, H., 1991a. Bacillariophyceae. 3. Teil: Centrales, Fragilariaceae, Eunotiaceae. In: Ettl, H., Gerloff, J., Heynig, H., Mollenhauer, D. (Eds.), Süßwasserflora von Mitteleuropa 2/3. Gustav Fischer Verlag, Stuttgart, p. 576.

Krammer, K., Lange-Bertalot, H., 1991b. Bacillariophyceae. 4. Teil: Achnanthaceae. Kritische Ergänzungen zu Navicula (Lineolate) und Gomphonema. In: Ettl, H., Gerloff, J., Heynig, H., Mollenhauer, D. (Eds.), Süßwasserflora von Mitteleuropa 2/4. Gustav. Fischer Verlag, Stuttgart, p. 437.

Krammer, K., Lange-Bertalot, H., 1997. Bacillariophyceae. 1. Teil: Naviculaceae. In: Ettl, H., Gerloff, J., Heynig, H., Mollenhauer, D. (Eds.), Süßwasserflora von Mitteleuropa 2/1. Gustav Fischer Verlag, Stuttgart, p. 876.

Kullman, L., 2000. The geoecological history of Picea abies in northern Sweden and adjacent parts of Norway. A contrarian hypothesis of postglacial tree immigration patterns. Geo-Öko 21, 141-172.

Kuoppamaa, M., Goslar, T., Hicks, S., 2009. Pollen accumulation rates as a tool for detecting land-use changes in a sparsely settled boreal forest. Vegetation History and Archaeobotany 18, 205-217.

Lamentowicz, Ł., Lamentowicz, M., Gąbka, M., 2008. Testate amoebae ecology and a local transfer function from a peatland in western Poland. Wetlands 28, $164-175$.

Latałowa, M., Tobolski, K., Nalepka, D., 2004. Pinus L. subgenus Pinus (subgen. Diploxyon (Koehne) Pilger) - Pine. In: Ralska-Jasiewiczowa, M. (Ed.), Late Glacial and Holocene History of Vegetation in Poland Based on Isopollen Maps. W. Szafer Institute of Botany, Kraków, pp. 165-177.

Latałowa, M., van der Knaap, W.O., 2006. Late Quaternary expansion of Norway spruce Picea abies (L.) Karst. in Europe according to pollen data. Quaternary Science Reviews 25, 2780-2805.

Leng, M.J., Marshall, J.D., 2004. Palaeoclimate interpretation of stable isotope data from lake sediment archives. Quaternary Science Reviews 23, 811-831.

Lewin, J.C., 1961. The dissolution of silica from diatom walls. Geochimica et Cosmochimica Acta 21, 182-198.

Lisitsyna, O.V., Giesecke, T., Hicks, S., 2011. Exploring pollen percentage threshold values as an indication for the regional presence of major European trees. Review of Palaeobotany and Palynology 166, 311-324.

Lister, G.S., Kelts, K., Zao, C.K., Yu, J., Niessen, F., 1991. Lake Qinghai, China: closed-basin lake levels and the oxygen isotope record for Ostracoda since the latest Pleistocene. Palaeogeography, Palaeoclimatology, Palaeoecology 84, 141-162.

Loginov, V.F., 1996. Klimat Belarusi. Nauka i tekhnika, Minsk, p. 223 (in Russian).

Lotter, A.F., Pienitz, R., Schmidt, R., 1999. Diatoms as indicators of environmenta change near arctic and alpine tree line. In: Stoermer, E.F., Smol, J.P. (Eds.), The Diatoms: Application to the Environmental and Earth Sciences. Cambridge University Press, Cambridge, pp. 205-226.

Lowe, J.J., Rasmussen, S., Bjorck, S., Hoek, W.Z., Steffense, J.B., Walker, M.J.C., Yu, Z.C., the INTIMATE Group, 2008. Synchronisation of palaeoenvironmental events in the North Atlantic region during the Last Termination: a revised protocol recommended by the INTIMATE group. Quaternary Science Reviews 27, 6-17.

Magny, M., de Beaulieu, J.L., Drescher-Schneider, R., Vannière, B., WalterSimonnet, A.V., Miras, Y., Millet, L., Bossuet, G., Peyron, O., Brugiapaglia, E., Leroux, A., 2007. Holocene climate changes in the central Mediterranean as recorded by lake-level fluctuations at Lake Accesa (Tuscany, Italy). Quaternary Science Reviews 26, 1736-1758.

Makhnach, N., Zernitskaya, V., Kolosov, I., Demeneva, O., Simakova, G., 2000. $\delta^{18} \mathrm{O}$ and $\delta^{13} \mathrm{C}$ in calcite of freshwater carbonate deposits as indicators of climatic and 
hydrological changes in the late-glacial and Holocene in Belarus. Journal of Geochemical Exploration 69-70, 435-440.

Makhnach, N., Zernitskaya, V., Kolosov, I.G., Simakova, G., 2004. Stable oxygen and carbon isotopes in Late Glacial-Holocene freshwater carbonates from Belarus and their palaeoclimatic implications. Palaeogeography, Palaeoclimatology, Palaeoecology 209, 73-101.

Makhnach, N., Zernitskaya, V., Kolosov, I., 2009. Stable carbon and oxygen isotopes and spore-pollen spectra in Late Glacial - Holocene carbonate sediments from lake Sergeyevskoye, Belarus. Lithosphere 1 (30), 103-114 (in Russian).

Makhnach, N.A., Zernitskaja, V.P., 2010. Climate changes in the Late Glacial - Holocene in Belarus (evidence from isotope-geochemical data on authigenic lacustrine calcites). Vesnik of Brest University, Series 5. Chemistry, Biology Earth Sciences 2, 81-94 (in Russian).

Margielewski, W., 2006. Records of the Late Glacial-Holocene climatic changes in landslide forms and deposits of the Beskid Makowski and Beskid Wyspowy Mts. area (Polish Outer Carpathians). Folia Quaternaria 76, 1-149.

Markova, A.K., Kolfschoten, T., Bohnke, S., Kosinsev, P.A., Mol, J., Puzachenko, A.Yu., Simakova, A.N., Smirnov, N.G., Verpoorte, A., Golovachev, I.V., 2008. Evolution of European Ecosystems During Pleistocene-Holocene Transition (24-8 kyr BP). KMK Scientific Press, Moscow, p. 556 (in Russian).

Marks, L., Pavlovskaya, I.E., 2007. Development of meltwater outflow during last glacial maximum in the middle Neman valley region, central Europe. Quaternary International 269 (Suppl.), 167-168.

Matveyev, A.V., Gurskij, B.N., Levitskaja, R.I., 1988. Reljef Belorussii. Nauka i tekhnika, Minsk, p. 320 (in Russian).

Matveyev, A.V., Krutous, E.A., Zernitskaya, V.P., 1993. Geochronology of the Holocene of the Belorussian Polessie. Radiocarbon 35 (3), 435-439.

McKenzie, J.A., 1985. Carbon isotopes and productivity in the lacustrine and marine environment. In: Stumm, W. (Ed.), Chemical Processes in Lakes. Wiley, New York, pp. 99-118.

Mook, W.G., Streurman, H.J., 1983. Physical and chemical aspects of radiocarbon dating. PACT 8, 31-55.

Moore, P.D., Webb, J.A., Collinson, M.E., 1991. Pollen Analysis. Blackwell Scientific, Oxford, p. 216.

Nesje, A., Dahl, S.O., Bakke, J., 2004. Were abrupt Lateglacial and early Holocene climate changes in NW Europe linked to freshwater outbursts to the North Atlantic and Arctic Oceans? The Holocene 14, 299-310.

Novik, A., Punning, J.M., Zernitskaya, V., 2010. The development of Belarusian lakes during the Late Glacial and Holocene. Estonian Journal of Earth Sciences 59 (1) 63-79.

Novenko, E.Yu., Volkova, E.M., Nosova, N.B., Zuganova, I.S., 2009. Late Glacial and Holocene landscape dynamics in the southern taiga zone of East European Plain according to pollen and macrofossil records from the Central Forest State Reserve (Valdai Hills, Russia). Quaternary International 207, 93-103.

O'Connell, M., Huang, C.C., Eicher, U., 1999. Multidisciplinary investigations, including stable-isotope studies, of thick Late-glacial sediments from Tory Hill, Co. Limerick, western Ireland. Palaeogeography, Palaeoclimatology, Palaeoecology 147, 169-208.

Punning, J.M., Zhukhovitskaya, A.L., Khursevich, G.K., Rachevskij, A.N., Martma, T.A., Putnik, H.E., 1988. Paleogeographic conditions of the formation of carbonate deposits of Lake Naroch. In: Yakushko, O.F. (Ed.), Lithology, Geochemistry and Stratigraphy of Continental Cainozoic Deposits of Belarus. NAN Belarusi, Minsk, pp. 101-110 (in Russian).

Ralska-Jasiewiczowa, M., Latałowa, M., Wasylikowa, K., Tobolski, K., Madeyska, E. Wright Jr., H.E., Turner, C., 2004. Late Glacial and Holocene History of Vegetation in Poland Based on Isopollen Maps. W. Szafer Institute of Botany, Polish Academy of Sciences, Kraków, p. 444.

Reille, M., 1992. Pollen et spores d'Europe et d'Afrique du nord. Laboratoire de Botanique historique et Palynologie, Marseille, p. 543.

Reimer, P.J., Bard, E., Bayliss, A., Beck, J.W., Blackwell, P.G., Bronk Ramsey, C., Buck, C.E., Cheng, H., Edwards, R.L., Friedrich, M., Grootes, P.M., Guilderson, T.P. Haflidason, H., Hajdas, I., Hatta, C., Heaton, T.J., Hogg, A.G., Hughen, K.A. Kaiser, K.F., Kromer, B., Manning, S.W., Niu, M., Reimer, R.W., Richards, D.A. Scott, E.M., Southon, J.R., Turney, C.S.M., van der Plicht, J., 2013. IntCal13 and Marine13 radiocarbon age calibration curves $0-50000$ years cal BP. Radiocarbon 55 (4), 1869-1887.

Rinterknecht, V.R., Pavlovskaya, I.E., Clark, P.U., Raisbeck, G.M., Yiou, F., Brook, E.J. 2007. Timing of the last deglaciation in Belarus. Boreas 36, 307-313.

San'ko, A.F., 1987. Neopleistocene of the North-eastern Belarus and Adjacent Region of the Russia. Nauka i Tehnika, Minsk, p. 178 (in Russian).

Savelieva, L.A., 2007. Features of the Migration of Spruce and Alder in the Holocene in North-West European Part of Russia (on the Basis of Palynological Analysis of Swamp and Lake Sediments) (Dissertation). St-Petersburg State University (in Russian).

Schwander, J., Eicher, U., Ammann, B., 2000. Oxygen isotopes of lake marl at Gerzensee and Leysin (Switzerland), covering the Younger Dryas and two minor oscillations, and their correlation to the GRIP ice core. Palaeogeography, Palaeoclimatology, Palaeoecology 159, 203-214.

Segerström, U., von Stedingk, H., 2003. Early-Holocene spruce, Picea abies (L.) Karst. in west central Sweden as revealed by pollen analysis. The Holocene 13, $897-906$.

Seppä, H., Weckström, J., 1999. Holocene vegetational and limnological changes in the Fennoscandian tree-line area as documented by pollen and diatom records from Lake Tsuolbmajärvi, Finland. Ecoscience 6, 621-635.
Spötl, C., Vennemann, T.W., 2003. Continuous-flow isotope ratio mass spectrometric analysis of carbonate minerals. Rapid Communications in Mass Spectrometry $17,1004-1006$

Subetto, D.A., Wohlfarth, B., Davydova, N.N., Sapelko, T.V., Björkman, L., Solovieva, N., Wastegård, S., Possnert, G., Khomutova, V.I., 2002. Climate and environment on the Karelian Isthmus, northwestern Russia, 13,000-9000 cal yrs BP. Boreas 31, 1-19.

Stančikaite, M., Kisielienè, D., Simniškytè, A., 2004. Vegetation response to the climatic and human impact changes during the Late Glacial and Holocene: case study of the marginal area of Baltija Upland, NE Lithuania. Baltica 17, 17-33.

Stančikaite, M., Šinkūnas, P., Šeirienè, V., Kisielienè, D., 2008. Patterns and chronology of the Lateglacial environmental development at Pamerkiai and Kašučiai, Lithuania, Quaternary Science Reviews 27, 127-147.

Stančikaite, M., Kisieliené, D., Moe, D., Vaikutienè, G., 2009. Lateglacial and early Holocene environmental changes in northeastern Lithuania. Quaternary International 207, 80-92.

Starkel, L., 2002. Younger Dryas-Preboreal transition documented in the fluvial environment of Polish rivers. Global and Planetary Change 35, 157-167.

Stockmarr, J., 1971. Tablets with spores used in absolute pollen analysis. Pollen et spores 13, 615-621.

Stuiver, M., Grootes, P.M., Braziunas, T.F., 1995. The GISP2 $\delta^{18}$ O climate record of the past 16.500 years and the role of the sun, ocean and volcanoes. Quaternary Research 44, 341-354.

Sweeney, C.A., 2004. A key for the identification of stomata of the native conifers of Scandinavia. Review of Palaeobotany and Palynology 128, 281-290.

Tantau, I., Reille, M., de Beaulieu, J.L., Farcas, S., 2006. Late Glacial and Holocene vegetation history in the southern part of Transylvania (Romania): pollen analysis of two sequence from Avrig. Journal of Quaternary Science 21, 49-61.

Terhürne-Berson, R., 2005. Changing Distribution Patterns of Selected Conifers in the Quaternary of Europe Caused by Climatic Variations (PhD thesis). Rheinischen Friedrich-Wilhelms-Universität Bonn, Bonn, Germany.

Turner, J.V., Fritz, P., Karrow, P.F., Warner, B.G., 1983. Isotopic and geochemical composition of marl lake waters and implications for radiocarbon dating of marl lake sediment. Canadian Journal of Earth Sciences 20, 599-615.

Vozniachuk, L.N., Valchik, M.A., 1978. Mopphology, Geology, and Developmaent of the Niemen Valley in Neopleistocene and Holocene. Nauka I tehnika, Minsk, p. 212 (in Russian).

Väliranta, M., Kaakinen, A., Kuhry, P., Kultti, S., Salonen, J.S., Seppä, H., 2011. Scattered late-glacial and early Holocene tree populations as dispersal nuclei for forest development in north-eastern European Russia. Journal of Biogeography 38, 922-932.

Velichko, A.A., Andreev, A.A., Klimanov, V.A., 1997. Climate and vegetation dynamics in the tundra and forest zone during the Late Glacial and Holocene. Quaternary International 41/42, 71-96.

Veski, S., Amon, L., Heinsalu, A., Reitalu, T., Saarse, L., Stivrinš, N., Vassiljev, J., 2012. Late-Glacial vegetation dynamics in the eastern Baltic region, a complete record since the Bølling (GI-1e). Quaternary Science Reviews 40, 39-53.

von Grafenstein, U., Erlenkeuser, H., Brauer, A., Jouzel, J., Johnsen, S.J., 1999. A midEuropean decadal isotope-climate record from 15,500 to 5,000 years BP. Science 284, 1654-1657.

Walker, M.J.C., 1995. Climatic changes in Europe during the last Glacial/Interglacial transition. Quaternary International 28, 63-76.

Wastegård, S., 1998. Deglaciation chronology and marine environments in southwestern Sweden. Boreas 27, 178-194.

Willis, K.J., van Andel, T.H., 2004. Trees or no trees? The environments of central and eastern Europe during the Last Glaciation. Quaternary Science Reviews 23, 2369-2387.

Wohlfarth, B., Bennike, O., Brunnberg, L., Demidov, I., Possnert, G., Vyahirev, S., 1999. AMS ${ }^{14} \mathrm{C}$ measurements and macrofossil analyses of a varved sequence near Pudozh, eastern Karelia, NW Russia stage. Boreas 28, 575-586.

Wohlfarth, B., Filimonova, L., Bennike, O., Björkman, L., Brunnberg, L., Lavrova, N., Demidov, I., Possnert, G., 2002. Late-glacial and early Holocene environmental and climatic change from Lake Tambichozero in southeastern Russian Karelia. Quaternary Research 58, 261-272.

Wohlfarth, B., Schwark, L., Bennike, O., Filimonova, L., Tarasov, P., Björkman, L. Brunnberg, L., Demidov, I., Possnert, G., 2004. Unstable early Holocene climatic and environmental conditions in northwestern Russia derived from a multidisciplinary study of a lake sediment sequence from Pichozero, southeastern Russian Karelia. The Holocene 14, 732-746.

Wohlfarth, B., Tarasov, P., Bennike, O., Lacourse, T., Subetto, D., Torssander, P., Romanenko, F., 2006. Late glacial and Holocene palaeoenvironmental changes in the Rostov-Yaroslavl' area, West Central Russia. Journal of Paleolimnology 35, $543-569$.

Wohlfarth, B., Lacourse, T., Bennike, O., Subetto, D., Tarasov, P., Demidov, I., Filimonova, L., Sapelko, T., 2007. Climatic and environmental changes in northwestern Russia between 15,000 and 8000 cal yr BP: a review. Quaternary Science Reviews 26, 1871-1883.

Makhnach, N.A., 1973. Basic Late Glacial and Holocene stages of Belarus (Osnovnie etapi pozdnelednikovja i golocena Belarusi). In: Yakushko, O.F. (Ed.), Problems of Anthropogen Palaeogeography in Belarus (Problemy paleogeografii antropogena Belorussii). NAN Belarusi, Minsk, pp. 76-95 (in Russian).

Zernitskaya, V.P., 1995. Stages of the main forest species distribution in Belarus in the Late Glacial time and the Holocene. In: Velichko, A.A. (Ed.), PAGES, PEP III: Climate and Environment Changes of East Europe during Holocene and Late- 
Middle Pleistocene. Institute of Geography of Russian Academy of Science, Moscow, pp. 28-37.

Zernitskaya, V.P., Zhukhovitskaya, A.L., Vlasov, B.P., Kurzo, B.V., 2001. Lake Dolgoe (Sedimentogenesis, Stratigraphy of Bottom Depositsand Stages of Development). Institut Geologicheskikh Nauk, NAN Belarusi, Minsk, p. 83 (in Russian).

Zernitskaya, V.P., Matveyev, A.V., Makhnach, N.A., Mihailov, N.D., 2005. Stratigraphic scheme of the Late Glacial and Holocene deposets of the Belarus. Lithosphere 1, 157-165 (in Russian).
Zernitskaya, V.P., Mikhailov, N.D., 2009. Evidence of early farming in the Holocene pollen spectra of Belarus. Quaternary International 203, 91-104.

Zernitskaya, V.P., Matveyev, A.V., Timireva, S.H., 2010. History of the Ivanisovka bog (Belarusian Polesje) forming in the Late Glacial and Holocene. Minsk. Lithosphere 1 (32), 20-30 (in Russian).

Zha, X.P., Zhao, Y.Y., Zheng, Y.F., 2010. An online method combining a Gasbench Il with continuous flow isotope ratio mass spectrometry to determine the content and isotopic compositions of minor amounts of carbonate in silicate rocks. Rapid Communications in Mass Spectrometry 24, 2217-2226. 